\title{
Bcl-2 family proteins in breast development and cancer: could Mcl-1 targeting overcome therapeutic resistance?
}

\author{
Michelle M. Williams ${ }^{1}$, Rebecca S. Cook ${ }^{1,2}$ \\ ${ }^{1}$ Department of Cancer Biology, Vanderbilt University School of Medicine, Nashville TN 27232, USA \\ ${ }^{2}$ Department of Vanderbilt Ingram Cancer Center, Nashville, TN 37232, USA \\ Correspondence to: \\ Rebecca S. Cook, e-mail: Rebecca.cook@vanderbilt.edu \\ Received: August 27, $2014 \quad$ Accepted: November 20, $2014 \quad$ Published: February 12, 2015
}

\section{ABSTRACT}

\begin{abstract}
Apoptosis, cell death executed by caspases, is essential to normal breast development and homeostasis. Pro-apoptotic and anti-apoptotic signals are tightly regulated in normal breast epithelial cells. Dysregulation of this balance is required for breast tumorigenesis and increases acquired resistance to treatments, including molecularly targeted therapies, radiation and chemotherapies. The pro-apoptotic or anti-apoptotic Bcl-2 family members interact with each other to maintain mitochondrial integrity and regulate cellular commitment to apoptosis. Among the anti-apoptotic $\mathrm{Bcl}-2$ family members, $\mathrm{Mcl}-1$ is uniquely regulated by numerous oncogenic signaling pathways. This review will focus on the role of $\mathrm{Bcl}-2$ family proteins in normal breast development, breast tumorigenesis and acquired resistance to breast cancer treatment strategies, while highlighting $\mathrm{Mcl-1}$ as a promising target to improve breast cancer tumor cell killing.
\end{abstract}

\section{INTRODUCTION}

The mammary gland is a dynamic tissue that undergoes many developmental stages, including puberty, pregnancy, lactation, post-lactational involution and lobular (menopausal) involution. Normal progression through these stages is regulated by numerous intracellular signaling cues that regulate the balance of mammary epithelial cell (MEC) proliferation and cell death. During puberty and pregnancy, MEC proliferation in the ductal and alveolar MEC lineages, respectively, outweighs cell death, allowing for expansion of each MEC population as needed. In contrast, cell death predominates over proliferation to cull milk-producing MECs once offspring are weaned, and to support lobular involution at menopause. In the breast, as in many other tissues, the cellular commitment to apoptosis is regulated by the intrinsic apoptotic pathway, which is comprised of the Bcl-2 family of proteins.

Two main subclasses of Bcl-2 proteins exist: antiapoptotic (Bcl2-A1, Bcl-2, Bcl-xL, Bcl-w and Mcl-1) and pro-apoptotic (Bad, Bak, Bax, Bid, Bik, Bim, Hrk, Noxa and Puma). Complex interactions among proand anti-apoptotic family members integrate signaling information to regulate cell death decisions. Due to the dynamic nature of the breast, characterized by sequential cycles of cell growth and cell death, Bcl-2 proteins are essential for development and homeostasis. Dysregulation of Bcl-2 proteins can impede development at several key stages. Furthermore, sustained Bcl-2 family dysregulation contributes to evasion of cell death, a hallmark of cancer. In the context of breast cancers, Bcl-2 dysregulation promotes innate or acquired treatment resistance. This review will focus on the role of Bcl-2 family members in breast development, tumorigenesis and therapeutic resistance, and will highlight one member, Mcl-1, as a promising therapeutic target in breast cancers.

\section{Bcl-2 proteins}

The intrinsic apoptotic pathway (IAP) is characterized by mitochondria outer membrane permeabilization (MOMP), resulting in release of cytochrome-c into the cytoplasm. This apoptotic pathway is governed by hierarchical interactions between pro-apoptotic and antiapoptotic Bcl-2 proteins. Every Bcl-2 family member contains at least one of the four Bcl-2 homology (BH) domains that are highly conserved from Caenorhabditis elegans to humans. $\mathrm{BH} 3$ domains facilitate and stabilize protein-protein interactions within the Bcl-2 family, which are critical for regulating MOMP [1]. 
Although not fully understood, most proposed mechanisms of MOMP suggest that Bcl-2 family effectors (Bak and Bax) heterodimerize to form higher-order oligomers, creating pores in the outer mitochondrial membrane (OMM) permitting cytochrome-c to escape into the cytoplasm [2, 3] (Figure 1A). Thus, activity of Bak/Bax is highly regulated at many levels. One level of regulation contributing to $\mathrm{Bak} / \mathrm{Bax}$ interaction is subcellular localization. Bak is associated with the OMM and sustains base-line activity of the intrinsic apoptotic pathway [4]. Meanwhile, Bax shuttles from the cytoplasm to the mitochondria in response to apoptotic cues, suggesting that Bax localization adjusts the sensitivity of cells to apoptotic stimuli. A cell with high Bak/Bax expression at the OMM is more 'primed' for cell death through the intrinsic apoptotic pathway. Additionally, Bak/Bax harbor BH1-3 domains required for Bak/Bax to interact with each other. However, Bak/Bax cannot interact until they undergo a dramatic conformational change induced by binding of pro-apoptotic Bcl-2 activators (Bim, Puma and Noxa) [5]. Activators only harbor $\mathrm{BH} 3$ domains and are thus referred to as 'BH3-only' proteins.

Other Bcl-2 proteins block activators from interacting with Bak/Bax oligomers, and are termed 'anti-apoptotic' Bcl-2 proteins (Bcl2-A1, Bcl-2, Bcl-xL, Bcl-w and Mcl-1) [6-8]. Anti-apoptotic Bcl-2 proteins contain BH1-4 domains, which generate a hydrophobic pocket that tightly binds with $\mathrm{BH} 3$ domains in the $\mathrm{BH} 3$-only activators and in Bak/Bax $[9,10]$. The BH3 motif of the anti-apoptotic $\mathrm{Bcl}-2$ proteins is central to their function, and is the key to drug development strategies aimed at inhibiting antiapoptotic Bcl-2 family members as a means to re-activate the intrinsic apoptotic pathway in cancer cells.

A final subclass of $\mathrm{Bcl}-2$ proteins, the $\mathrm{Bcl}-2$ sensitizers, is comprised of $\mathrm{BH} 3$-only proteins $\mathrm{Bad}$, Bik, Hrk and Noxa that bind to BH1-4 domains of antiapoptotic Bcl-2 proteins tightly, but do not bind to Bcl2 effectors [7]. While sensitizers cannot activate Bak/ Bax directly, their abundance can neutralize the inhibitor effects of the anti-apoptotic proteins, thus rendering cells more 'sensitive' to apoptotic stimuli. Thus, BH3-only proteins are pro-apoptotic forces that cooperate to enhance Bak/Bax-mediated MOMP. Importantly both BH3-only activators and sensitizers are rapidly upregulated in response to oxidative stress, DNA damage, endoplasmic reticulum stress or other insults that may provoke cell death through varying molecular mechanisms, including transcriptional regulation, subcellular localization and phosphorylation [11-14]. Because commitment to cell death occurs only when the complex interplay between pro- and anti-apoptotic Bcl-2 classes favors apoptosis (Figure 1B), the fluctuation in expression/localization/ activation of BH3-only proteins in response to cellular cues liken the BH3-only proteins to a cellular rheostat, constantly adjusting and tuning the sensitivity of cells to apoptosis.

\section{Apoptosis is required in normal mammary gland development}

The intrinsic cell death pathway is essential to several developmental phases of the mammary gland (Table 1). In response to hormonal stimuli during puberty, MECs within the terminal end buds (TEBs), the clubshaped structures at the distal mammary epithelial tips, proliferate and collectively invade the surrounding stroma. While differentiation of epithelial progenitors in the TEB populates the ducts with solid cords of mature luminal MECs, programmed cell death canalizes the ducts, resulting in lumen formation. Transgenic overexpression of anti-apoptotic Bcl-2 impaired TEB structure and disrupted ductal formation [15]. Similarly, genetic ablation of the BH3-only activator Bim delayed lumen formation due to reduced apoptosis in TEBs [16], demonstrating that $\mathrm{Bcl}-2$ family proteins govern ductal lumen formation in the developing mammary gland during puberty.

Once the ductal epithelium is established, other MECs throughout the breast, the alveolar progenitor cells, undergo hormonally-induced growth during the menstrual cycle (in humans) or estrus cycle (in rodents and other mammals). This expansion prepares the MEC population for rapid pregnancy-induced growth of the alveolar (milk-producing) epithelium. However, in the absence of pregnancy, the expanded alveolar progenitor population is removed by cell death. Thus, apoptosis within the breast occurs with each hormonal cycle throughout a woman's reproductive lifespan.

In the event of pregnancy massive expansion of the alveolar (milk-producing) epithelium occurs in preparation for nursing. The milk-producing cells are maintained while offspring continue to nurse. Once weaning occurs, the alveolar epithelium undergoes massive cell death in a tissue remodeling event termed post-lactational involution. During this short period of time (7-10 days in mice, 6-12 months in women), up to $80 \%$ of all MECs undergo cell death. Evidence of Bcl-2 family regulation of this event is abundant. High expression levels of the anti-apoptotic proteins $\mathrm{Bcl}-2$ and $\mathrm{Bcl}-\mathrm{w}$ during lactation are rapidly down-regulated during post-lactational involution [17], allowing for induction of cell death. Disruption of the Bcl-2 family balance through transgenic Bax overexpression results in cell death during lactation instead of during involution, resulting in premature involution [18]. Furthermore, genetic Bcl-xL ablation in the mammary epithelium dramatically increases cell death during post-partum involution [19]. Collectively, these studies demonstrate that Bcl-2 family proteins are key regulators of cell survival during lactation and are critical for inducing cell death of the milk producing epithelium once lactation ceases.

Less is known regarding the Bcl-2 family in lobular (menopausal) involution of the breast. However, increasing evidence suggests that the extent to which 
A.

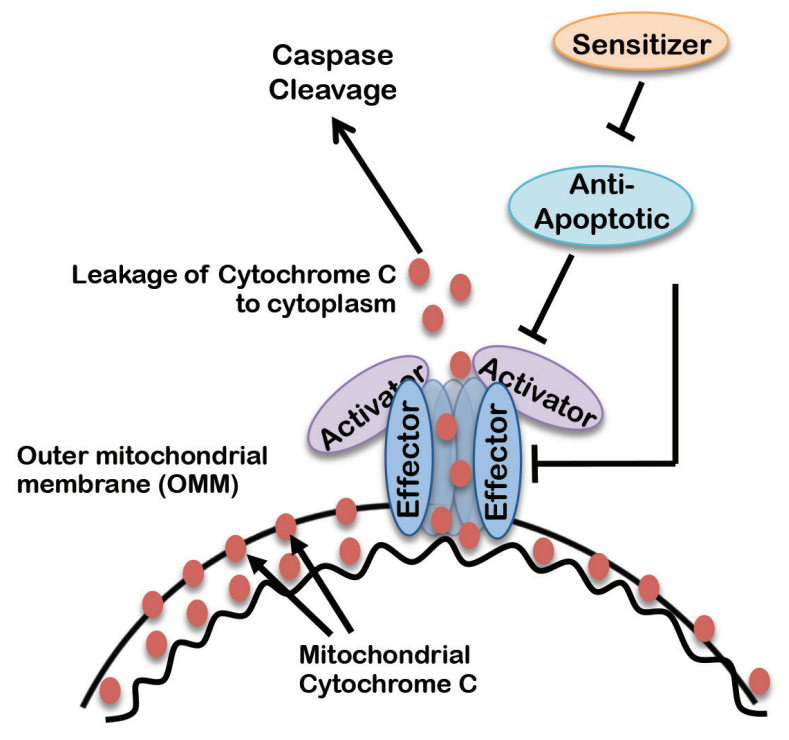

B.
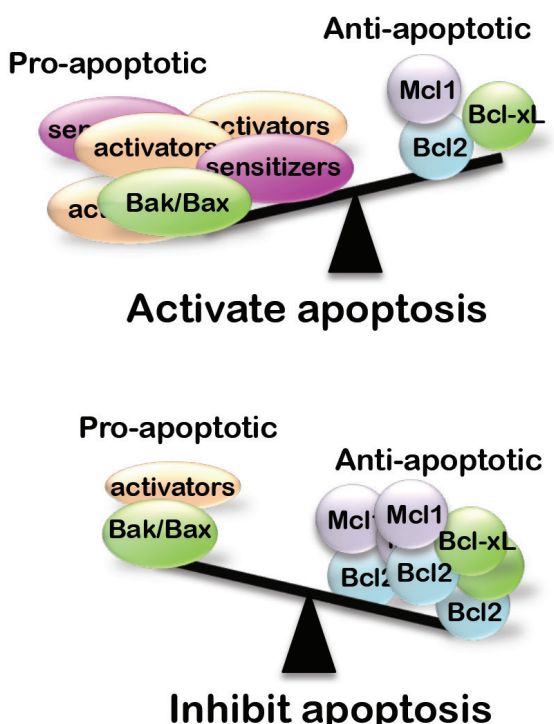

Inhibit apoptosis
C.
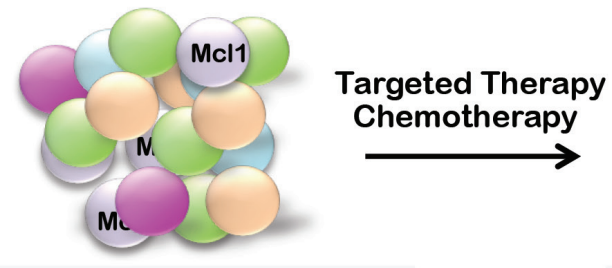

A minority of $\mathrm{Mcl}-1$ overexpressors in a heterogenous tumor cell population

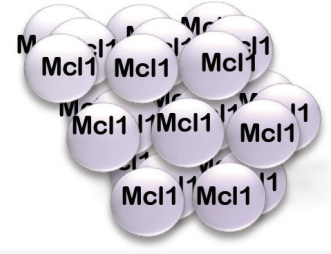

Clonal selection for $\mathrm{Mcl}-1$ overexpression in therapy resistant tumor cells

\section{D.}

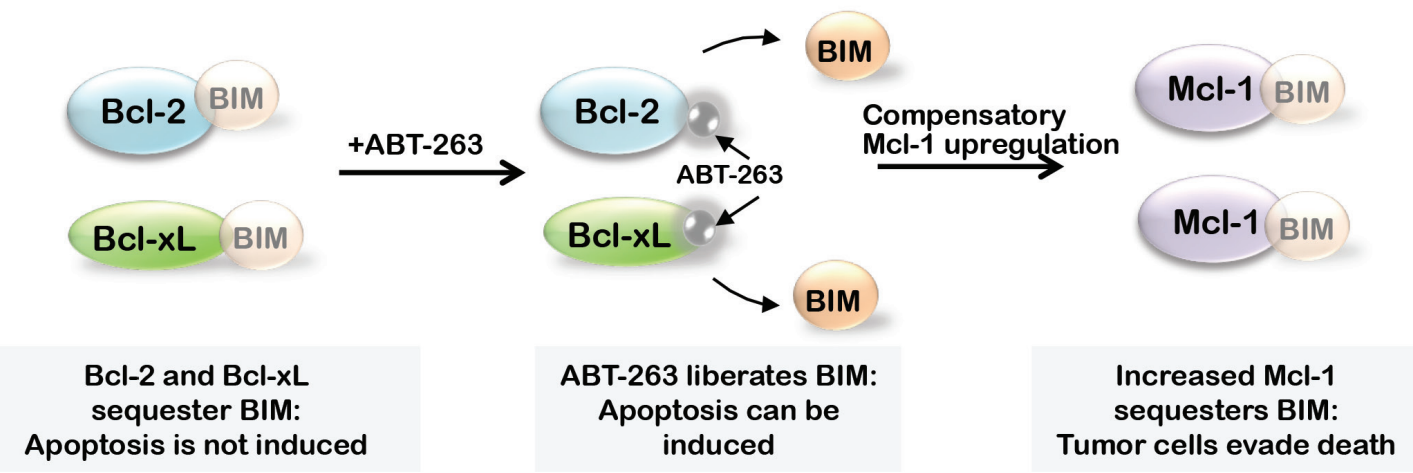

Figure 1: (A) Bcl-2 family member effector proteins (Bax and Bak) oligomerize and permeablize the outer mitochondrial membrane (OMM) upon activator-protein (Bid, Bim and Puma) binding. Cytochrome-c is able to escape the mitochondria through Bak/Bax pores, leading to caspase cleavage and apoptosis. Anti-apoptotic Bcl-2 family members (A1, Bcl-2, Bcl-xL, Bcl-w and Mcl-1) inhibit apoptosis by preventing effector protein oligomerization or Bak/Bax activation. Sensitizer proteins (Bad, Bik and Noxa) counteract anti-apoptotic members by sequestering anti-apoptotic proteins. (B) When the balance of active Bcl-2 proteins favors pro-apoptotic over anti-apoptotic family members, apoptosis is initiated. (C-D) Proposed models of Mcl-1 expression or activity supporting resistance to standard chemotherapies or targeted therapies (C) and BH3-mimetics (B). 
Table 1: Transgenic misregulation of Bcl-2 family proteins in mouse models of mammary development and breast tumorigenesis

\begin{tabular}{|c|c|c|c|c|c|}
\hline Class & $\begin{array}{l}\text { BCL2 } \\
\text { Factor }\end{array}$ & $\begin{array}{l}\text { Genetically } \\
\text { Engineered Model }\end{array}$ & Developmental Phenotype & Breast Cancer Phenotype & Ref. \\
\hline \multirow[t]{5}{*}{ Effector } & Bak & $\mathrm{n} / \mathrm{a}$ & $\mathrm{n} / \mathrm{a}$ & $\mathrm{n} / \mathrm{a}$ & $\mathrm{n} / \mathrm{a}$ \\
\hline & \multirow{4}{*}{ Bax } & WAP-Bax & $\begin{array}{l}\text { Impairs growth of alveolar } \\
\text { MECs; premature apoptosis/ } \\
\text { involution }\end{array}$ & $\mathrm{n} / \mathrm{a}$ & {$[1]$} \\
\hline & & MMTV-Myc X a $^{++/}$ & $\mathrm{n} / \mathrm{a}$ & Altered tumor multiplicity & {$[2]$} \\
\hline & & $B a x^{-\alpha}$ & Normal involution & Not highly tumorigenic & {$[3]$} \\
\hline & & C3(1)-TAg X Bak $k^{+/-}$ & $\mathrm{n} / \mathrm{a}$ & $\begin{array}{l}\text { Reduces apoptosis at preneoplastic } \\
\text { stage }\end{array}$ & {$[4]$} \\
\hline \multirow[t]{2}{*}{ Activator } & Bim & $\mathrm{Bim}^{-/-}$ & TEB/lumen filling & $\mathrm{n} / \mathrm{a}$ & {$[10]$} \\
\hline & $\begin{array}{l}\text { Bid } \\
\text { Puma }\end{array}$ & $\mathrm{n} / \mathrm{a}$ & $\mathrm{n} / \mathrm{a}$ & $\mathrm{n} / \mathrm{a}$ & $\mathrm{n} / \mathrm{a}$ \\
\hline Sensitizer & $\begin{array}{l}\text { Bad } \\
\text { Bik } \\
\text { Noxa }\end{array}$ & $\mathrm{n} / \mathrm{a}$ & $\mathrm{n} / \mathrm{a}$ & $\mathrm{n} / \mathrm{a}$ & $\mathrm{n} / \mathrm{a}$ \\
\hline \multirow[t]{4}{*}{$\begin{array}{l}\text { Anti- } \\
\text { apoptotic }\end{array}$} & \multirow[t]{2}{*}{ Bcl-2 } & WAP-Bcl2 & $\begin{array}{l}\text { Reduces apoptosis in TEBs, } \\
\text { lumen filling during puberty; } \\
\text { decreases cell death during } \\
\text { involution }\end{array}$ & $\begin{array}{l}\text { Accelerated MMTV-Myc- } \\
\text { induced mammary tumorigenesis, } \\
\text { carcinogen-induced breast tumor } \\
\text { formation is delayed }\end{array}$ & {$[3,5-7]$} \\
\hline & & WAP-TAg;WAP-Bcl2 & na & Reduced tumor latency & {$[8]$} \\
\hline & Bcl-xL & $\begin{array}{l}\text { WAP-Cre X Bcl-xL } L^{f l f t} \\
\text { MMTV-Cre X Bcl-xL } L^{f l f t}\end{array}$ & $\begin{array}{l}\text { Decreased apoptosis during } \\
\text { involution }\end{array}$ & $\mathrm{n} / \mathrm{a}$ & {$[9]$} \\
\hline & $\begin{array}{l}\mathrm{A} 1 \\
\mathrm{Bcl}-\mathrm{w} \\
\mathrm{Mcl}-1\end{array}$ & $\mathrm{n} / \mathrm{a}$ & $\mathrm{n} / \mathrm{a}$ & $\mathrm{n} / \mathrm{a}$ & $\mathrm{n} / \mathrm{a}$ \\
\hline
\end{tabular}

n/a - not available.

${ }^{1}$ Rucker, E.B., 3rd, et al., Forced involution of the functionally differentiated mammary gland by overexpression of the proapoptotic protein bax. Genesis, 2011. 49:24-35.

${ }^{2}$ Jamerson, M.H., et al., Bax regulates c-Myc-induced mammary tumour apoptosis but not proliferation in MMTV-c-myc transgenic mice. Br J Cancer, 2004. 91:1372-9.

${ }^{3}$ Schorr, K., et al., Gain of Bcl-2 is more potent than bax loss in regulating mammary epithelial cell survival in vivo. Cancer Research, 1999. 59:2541-5.

${ }^{4}$ Shibata, M.A., et al., Haploid loss of bax leads to accelerated mammary tumor development in C3(1)/SV40-TAg transgenic mice: reduction in protective apoptotic response at the preneoplastic stage. EMBO J, 1999. 18:2692-701.

${ }^{5} \mathrm{Jager}, \mathrm{R}$., et al., Overexpression of Bcl-2 inhibits alveolar cell apoptosis during involution and accelerates c-myc-induced tumorigenesis of the mammary gland in transgenic mice. Oncogene, 1997. 15:1787-95.

${ }^{6}$ Humphreys, R.C., et al., Apoptosis in the terminal endbud of the murine mammary gland: a mechanism of ductal morphogenesis. Development, 1996. 122:4013-22.

${ }^{7}$ Murphy, K.L., et al., Bcl-2 expression delays mammary tumor development in dimethylbenz(a)anthracene-treated transgenic mice. Oncogene, 1999. 18:6597-604.

${ }^{8}$ Furth, P.A., et al., Loss of anti-mitotic effects of Bcl-2 with retention of anti-apoptotic activity during tumor progression in a mouse model. Oncogene, 1999. 18:6589-96.

${ }^{9}$ Walton, K.D., et al., Conditional deletion of the bcl-x gene from mouse mammary epithelium results in accelerated apoptosis during involution but does not compromise cell function during lactation. Mech Dev, 2001. 109:281-93.

${ }^{10}$ Mailleux AA, Overholtzer M, Schmelzle T, Bouillet P, Strasser A, Brugge JS. BIM regulates apoptosis during mammary ductal morphogenesis, and its absence reveals alternative cell death mechanisms. Dev Cell, 2007. 12:221-234. 
lobular involution occurs is directly proportional to a woman's risk of developing post-menopausal breast cancer. Nearly $70 \%$ of all breast cancers occur in post-menopausal women. It is therefore important to understand the molecular mechanisms contributing to lobular involution. Given the importance of Bcl-2 proteins in other stages of breast development, these observations support the exploration of Bcl-2 family proteins in lobular involution.

\section{Bcl-2 family in breast cancer formation and progression}

Anti-apoptotic Bcl-2 proteins were first acknowledged as oncogenes in 1984 upon discovery of Bcl-2 dysregulation due to the chromosomal translocation $\mathrm{t}(14 ; 18)$ that was a driving factor in B-cell leukemia [20], changing the oncogene paradigm to include anti-apoptotic proteins. Evasion of cell death is now acknowledged as a hallmark of cancer, required to overcome the counterbalancing effects of cell death on enhanced cell proliferation [21]. As an illustration of this point, studies performed in three-dimensional acinar cultures of untransformed MECs demonstrated that oncogene-induced proliferation was insufficient to support lumen filling due to equally increased cell death $[22,23]$. However, $\mathrm{Bcl}-2$ and Bcl-xL over-expression in combination with oncogene-induced proliferation resulted in lumen filling, a morphological characteristic of ductal carcinoma in situ (DCIS), an early pre-malignant state [24]. These results demonstrated that pro-proliferative and antiapoptotic signals cooperate in early MEC transformation and that anti-apoptotic Bcl-2 proteins contribute to this process.

Consistent with these findings, although transgenic overexpression of $\mathrm{Bcl}-2$ alone did not generate mammary tumors, c-Myc induced [25] and SV40 Large T-antigen (TAg)-induced [26] mammary tumors developed at a remarkably faster rate in the context of Bcl-2 overexpression. Similarly, genetic Bax ablation accelerated TAg-induced mammary tumor progression [27]. In human breast cancers, up to $80 \%$ of $M Y C$-amplified triple negative breast cancer (TNBC) cases harbor MCL1 coamplification [28]. Further, Bcl-2 expression frequently correlates with Estrogen Receptor (ER) expression levels in $\mathrm{ER}^{+}$breast cancers [29]. Taken together, these studies suggest that anti-apoptotic $\mathrm{Bcl}-2$ proteins may cooperate with pro-proliferative signals to support breast cancer initiation and progression.

\section{Bcl-2 family in therapeutic resistance}

The goal of chemotherapies, therapeutic radiation and molecularly targeted drugs is effective tumor cell killing. However, this goal is often thwarted by increased anti-apoptotic and/or decreased pro-apoptotic
Bcl-2 protein activity or expression. In the context of chemotherapy, clinical breast cancer specimens biopsied before and after a course of pre-operative neoadjuvant chemotherapy displayed increased Bcl-2 in residual posttreatment tumor cells [30]. Furthermore, metastatic human breast cancer cell lines with high Bcl-2 levels were less sensitive to taxanes [31] and Adriamycin [32]. MCL1 amplification was more frequently observed in chemorefractory TNBC samples as compared to the total TNBC sample population [28]. Together, these studies suggest that anti-apoptotic Bcl-2 family proteins interfere with chemotherapy-induced apoptosis in breast cancers.

Bcl-2 family proteins also mediate resistance to targeted breast cancer therapies. The anti-HER2 antibody, trastuzumab, is clinically approved for use in $20 \%$ of all breast cancers that exhibit HER 2 gene amplification. However, many HER2-amplified tumors display innate trastuzumab resistance, while others rapidly acquire trastuzumab resistance. Trastuzumabresistant $\mathrm{HER}^{+}$breast cancer cell lines frequently upregulate Bcl-2 and decrease $\mathrm{Bax}$ as a means of enhancing cell survival [33].

Nearly $65 \%$ of breast cancers are $\mathrm{ER}^{+}$and are thus treated with drugs that interfere with ER signaling, such as selective ER modulators (SERMS, e.g. tamoxifen), selective ER downregulators (SERDS, e.g., fulvestrant) or drugs that decrease circulating estrogen levels, like aromatase inhibitors (AIs, e.g., exemestane). Although these targeted therapies improve outcome for many patients with $\mathrm{ER}^{+}$breast cancers, $15-20 \%$ relapse within 5 years of treatment withdrawal [34]. Tamoxifen treated $\mathrm{ER}^{+}$breast cancers often increase $\mathrm{Bcl}-2$ and $\mathrm{Bcl}-\mathrm{xL}$ levels, decreasing acute tumor response to Tamoxifen and increasing long-term tamoxifen resistance [35]. Using estrogen deprivation of $\mathrm{ER}^{+}$human breast cancer cell lines as a model of AI treatment, one study showed that cell survival under these conditions is supported by increased activity of Bcl-2 at the mitochondria [36]. Upon long-term estrogen deprivation, endoplasmic reticulum chaperone proteins sequester the pro-apoptotic Bcl-2 protein, Bik, preventing its translocation to the mitochondria, allowing Bcl-2 to inhibit Bak/Bax-mediated apoptosis. Thus, Bcl2 protein dysregulation favoring expression or activity of anti-apoptotic family members is a driver of resistance to HER2 and ER-targeted therapies.

\section{Targeting Bcl-2/Bcl-xL/Bcl-w to enhance breast tumor cell killing}

Based on observations that tumors require evasion of cell death, and that Bcl-2 family anti-apoptotic proteins are frequently overexpression or hyper-activated in cancers, it is likely that certain cancers maybe particularly sensitive to targeted inhibition of anti-apoptotic Bcl-2 proteins. This hypothesis is the basis for the relatively recent development of BH3-mimetics, a class of small molecule Bcl-2 family 
inhibitors that tightly bind the hydrophobic BH3-binding motif within anti-apoptotic Bcl-2 proteins, allowing for release of Bcl-2 activators from sequestration by Bcl-2 inhibitors, MOMP and caspase-dependent cell death [37]. Several BH3 mimetic have been developed, including the Bcl-2/Bcl-xL/Bcl-w inhibitor ABT-263 [38], which binds to $\mathrm{Bcl}-2, \mathrm{Bcl}-\mathrm{xL}$ and $\mathrm{Bcl}-\mathrm{w}$ in a manner similar to the $\mathrm{BH} 3-$ domain of the sensitizer BAD. Although ABT-263 has shown promising anti-cancer activity in chronic lymphocytic leukemia (CLL) as a single agent [39], ABT-263 caused ontarget induction of apoptosis in platelets [40], limiting its clinical utility. The Bcl-2 selective inhibitor ABT-199 spares platelets, which require Bcl-xL signaling [41, 42]. Despite the suspension of initial clinical trials using ABT-199 in CLL patients due to fatal levels of tumor lysis, ABT-199 trails in CLL and other cancers are ongoing [43].

Although only limited information regarding BH3-mimetic in clinical breast cancers is available, pre-clinical models support the use of BH3-mimetics in combination with existing breast cancer treatment strategies. For example, Bcl-2 is overexpressed in about $85 \%$ of $\mathrm{ER}^{+}$breast cancers, perhaps due to the fact that its promoter is directly bound and transactivated by ER $\alpha$ [44]. Patient-derived $\mathrm{ER}^{+}$breast cancer xenografts treated with tamoxifen in combination with the Bcl-2/Bcl-xL/ Bcl-w inhibitor ABT-737 [37], an analogue of ABT-263, displayed decreased tumor growth and increased tumor cell death [45]. Similar results were obtained using Tamoxifen in combination with ABT-199, the Bcl-2 selective inhibitor. However, $\mathrm{BH} 3$-mimetics alone failed to decrease tumor growth or induce apoptosis in this model. In models of TNBC, ABT-737 sensitized patient-derived basal-like breast cancer xenografts to the chemotherapeutic agent docetaxel [46] and increased cell death in irradiated TNBC in cell culture and in vivo [47]. GX15-070 (obatoclax), a pan Bcl-2 family inhibitor, cooperated with lapitinib (an EGFR/HER2 inhibitor) to induce cell death in HER2 ${ }^{+}$breast cancer cells treated with radiotherapies [48]. These studies suggest that targeting Bcl-2 family proteins in combination with current chemotherapies and targeted therapies may increase tumor cell killing and therefore improve the outcome of patients with breast cancer. Although no current clinical trials are studying the effects of anti-apoptotic Bcl-2 family member inhibition in breast cancers alone, initial Phase I studies in small cell lung cancers suggest that ABT-263 is safe and well tolerated in patients with solid tumors [49]. Additionally, Phase I studies are underway to determine the efficacy of ABT-263 with paclitaxel, gemcitabine and sorafinib, in solid tumors, which could include breast cancers [50-52].

\section{Targeting Mcl-1 in breast cancer}

Although there is strong preliminary evidence supporting the roles of Bcl-2 and Bcl-xL in breast tumor formation and therapeutic resistance, high $\mathrm{Bcl}-2$ protein levels in human breast cancer samples tend to correlate with a favorable prognosis [53]. Furthermore, according The Cancer Genome Atlas (TCGA) genetic amplification of BCL2 and BCL2L1 (encoding Bcl-xL) occurs in less than $3 \%$ of luminal $\mathrm{B}$ and TNBC cases [54], implying that $\mathrm{BH} 3$-mimetic targeting of $\mathrm{Bcl}-2$ and $\mathrm{Bcl}-\mathrm{xL}$ may not be beneficial in most breast cancer subtypes. However, targeting of other anti-apoptotic Bcl-2 family members, like Mcl-1, may provide an alternative approach.

Currently, little is known regarding the contribution of Mcl-1 to breast cancer formation and therapeutic response. However, unlike other Bcl-2 family members, Mcl-1 has a short half-life and is highly regulated at the transcriptional, post-transcriptional, translational and post-translational levels $[55,56]$ by various oncogenic signaling pathways (Figure 2), including the mitogen activated protein kinase (MAPK) pathway [57], the mTOR pathway [58] and the phosphatidylinositol-3 kinase (PI3K) pathway [59]. These oncogenic signaling pathways rapidly increase Mcl-1 to promote cell survival, suggesting that Mcl-1 may be an important mediator of apoptotic escape and therapeutic resistance in many cancers, including breast cancers. This hypothesis is supported by the fact that the dual PI3K/mTOR inhibitor NVP-BEZ235 was found to decrease Mcl-1 levels in ovarian carcinomas cells [60]. Additionally, Mcl-1 expression was inhibited by targeting of the mTOR pathway using the rapalouge RAD001/everolimus, promoting increased tumor cell killing in in vivo models of colon cancer [61].

Specifically in the context of breast cancer, Mcl1 has genetic or mRNA upregulation in 16/58 (28\%) of human breast cancer cell lines as curated by the CCLE (Figure 3), while Bcl-2 is only aberrantly upregulated in 2/58 cases (3\%) [54]. Additionally, expression of Mcl1 in human breast cancer samples correlates with high tumor grade and a dramatic decrease in patient survival regardless of subtype [62]. MCL1 is also genetically amplified in $9 \%$ of luminal B breast cancers [54] and $54 \%$ of TNBCs after treatment with neoadjuvant chemotherapies [28], suggesting that $\mathrm{Mcl}-1$ may represent a more desirable target over Bcl-2/Bcl-xL in some breast cancers. Indirect evidence that targeting of Mcl-1 in combination with lapitinib could sensitize breast cancer cells to radiotherapies was gained using the pan-BCL2 inhibitor obatoclax, a BH3-mimetic that displaces BIM from all anti-apoptotic BCL2 family members. These preliminary studies suggest that Mcl-1 may support the escape of breast cancer cells from therapy-induced cell death (Figure 1C), suggesting that targeting Mcl-1 may be beneficial to improving the outcome of breast cancer patients, particularly those with Mcl-1 amplification [63].

The importance of targeting Mcl-1 in breast cancers is further supported by extensive studies conducted on anti-apoptotic Bcl-2 family proteins in other cancers. These studies suggest that high Mcl-1 expression or Mcl-1 upregulation confer resistance to the 


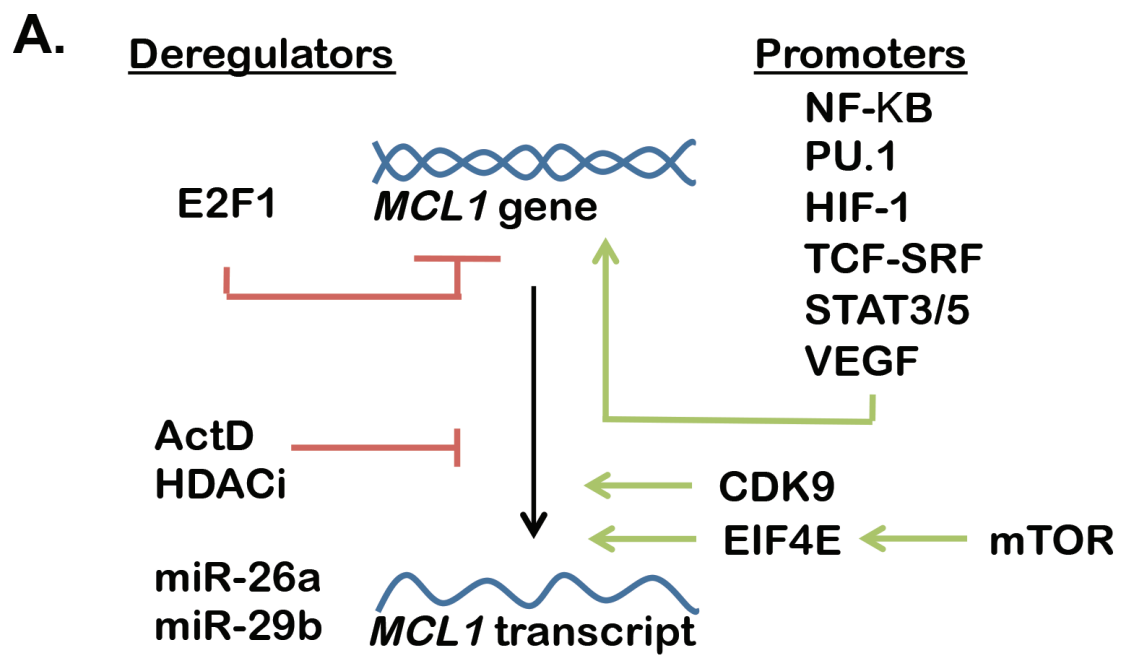

B. Phosphorylation of Mcl-1
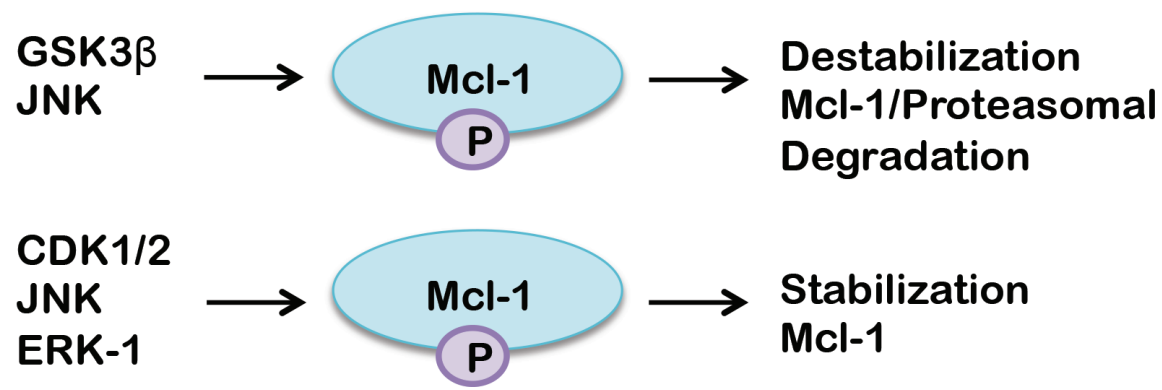

\section{Ubiquitylation of $\mathrm{Mcl}-1$}

DUB

Usp9x

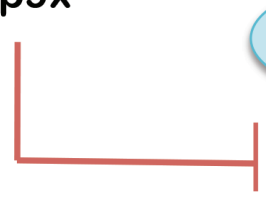

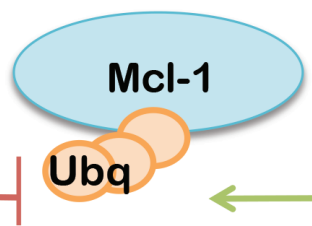

E3 Ligases

Fbxw7

Mule

$\beta-\operatorname{TrCP}$

Figure 2: (A) Transcriptional, translational and post translational mechanisms of Mcl-1 regulation (promoters support Mcl-1 expression, while deregulators decrease Mcl-1 expression). (B-C) A complex interplay of phosphatases (B), ubiquitinases and deubiquitinases (DUBs) (C) regulate Mcl-1 stability through activation or suppression of ubiquitin-mediated proteasomal degradation of Mcl-1 (further reviewed in $[55,56])$.

Bcl-2/Bcl-xL/Bcl-w inhibitor ABT-263 in leukemias, lymphomas, melanomas and lung cancers [64-69]. These findings highlight the potential compensatory nature of anti-apoptotic Bcl-2 family members and suggest that the maximum tumor cell killing may only be achieved under conditions where Bcl-2, Bcl-xL, Bcl-w and Mcl-1 are inhibited (Figure 1D). To overcome this limitation, recent efforts have focused on isolating and developing an Mcl-1 specific inhibitor, as reviewed by Belmar J and
Fesik 2014 [70]. Unfortunately, these efforts have been met with limited success due to: (1) conflicting reports on the efficacy of these drugs to inhibit Mcl-1 in various cancer cell lines, (2) low affinity of these drugs for Mcl1 and (3) lack of in vivo data supporting the efficacy of these inhibitors. However, the discovery of an Mcl-1specific inhibitor is still a relatively new field and further efforts may identify a potent Mcl-1-speicifc inhibitor with immense clinical/translational value. 


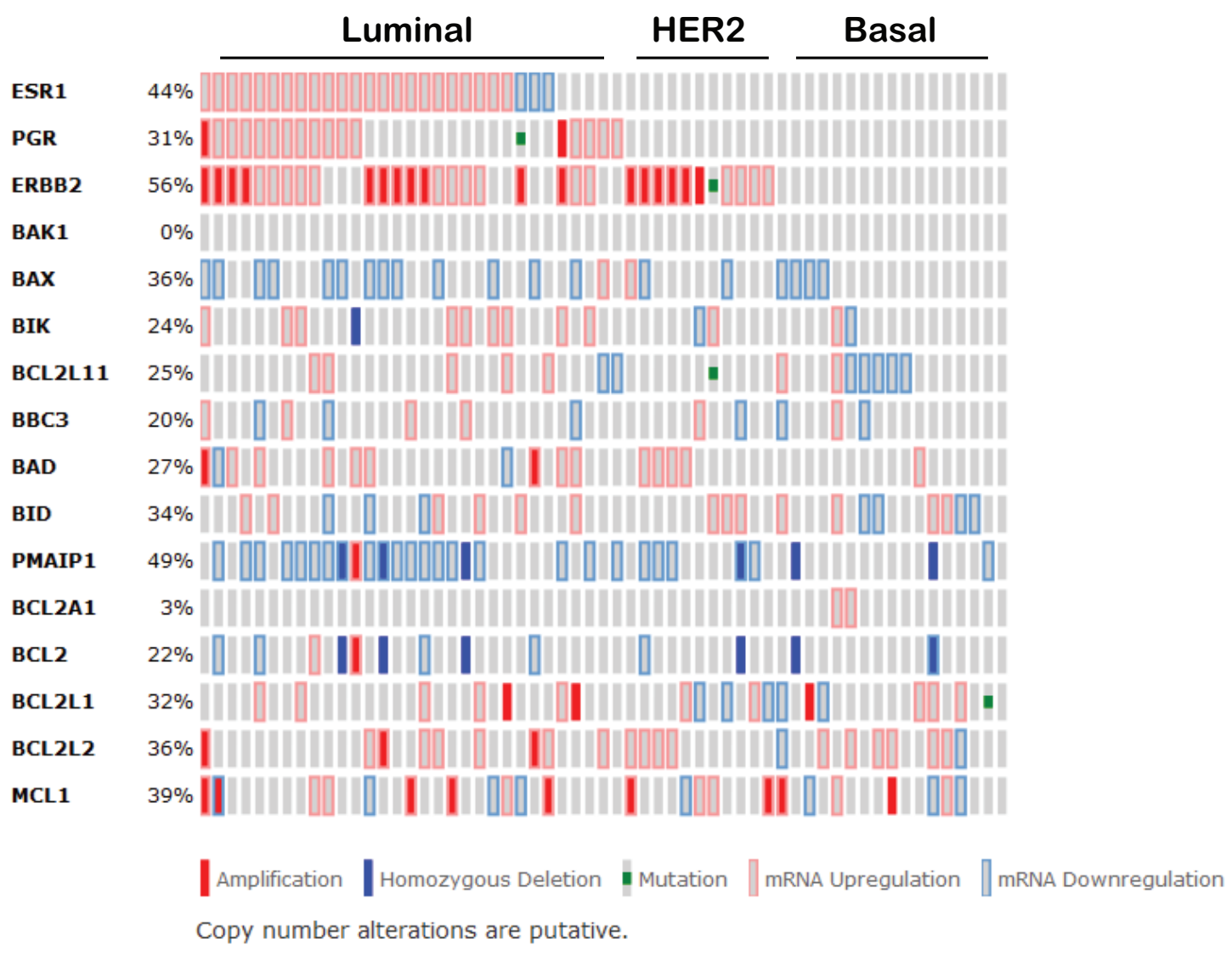

Figure 3: Expression signature of Bcl-2 family proteins in human breast cancer cell lines according to the cancer cell line encyclopedia as curated by the cancer genome atlas. $(\mathrm{BCL} 2 \mathrm{~L} 11=\mathrm{BIM}, \mathrm{BBC} 3=\mathrm{PUMA}, \mathrm{PMAIP} 1=\mathrm{NOXA}, \mathrm{BCL} 2 \mathrm{~L} 1=$ Bcl-xL, BCL2L2 = Bcl-w).

Although preliminary studies in breast cancers demonstrate that inhibiting Bcl-2 or Bcl-2/Bcl-xL/Bcl-w in combination with targeted therapies is sufficient to dramatically increase tumor cell killing and survival, this might not be the case for all breast cancers, particularly those with MCL1-amplification. Instead, Mcl-1 alone, or in combination with other anti-apoptotic Bcl-2 family members, may be an essential driver of tumor progression and mediator of therapeutic resistance in breast cancers.

\section{Future directions}

Mcl-1 remains understudied in breast cancers as compared to other Bcl-2 family anti-apoptotic proteins. Regardless, it is clear that anti-apoptotic Bcl-2 family members influence the formation, progression and therapeutic response of breast cancers. Recent efforts in developing an Mcl-1 specific inhibitor have been reported $[71,72]$, although their efficacy in breast cancers and preclinical testing remains on the horizon. Currently, inhibition of the numerous pathways that regulate Mcl-1 expression and stability are viable strategies to block the oncogenic effects of Mcl-1 (Figure 2). Importantly, inhibitors for many of these pathways are approved for clinical use in many cancers, including inhibitors of MAPK, mTOR and PI3K pathways. These inhibitors may provide a feasible and rapidly translatable approach to limiting Mcl-1 activity in breast cancers. A potential disadvantage to this approach is deciphering which pathway is the most reasonable for achieving targeted Mcl-1 inhibition for each patient. Further, since multiple signaling pathways converge on Mcl-1 numerous mechanisms exist to re-establish Mcl-1 signaling, suggesting that many avenues exist to promote therapeutic escape. Thus, the observations highlighted in this review support a continued effort to design Mcl-1specific inhibitors, while investigation into the role of Mcl1 in mammary gland development and breast cancer will be essential to maximize the clinical value of emerging Mcl-1 inhibitors.

\section{CONFLICTS OF INTEREST}

The authors have no conflicts of interest to declare. 


\section{FUNDING}

This work was supported by the National Institutes of Health R01 CA143126 (RSC).

\section{REFERENCES}

1. Kelekar A, Thompson CB. Bcl-2-family proteins: the role of the BH3 domain in apoptosis. Trends Cell Biol. 1998; $8: 324-330$.

2. Chipuk JE, Bouchier-Hayes L, Green DR. Mitochondrial outer membrane permeabilization during apoptosis: the innocent bystander scenario. Cell Death Differ. 2006; 13:1396-1402.

3. Kroemer G, Galluzzi L, Brenner C. Mitochondrial membrane permeabilization in cell death. Physiol Rev. 2007; 87:99-163.

4. Kim H, Tu HC, Ren D, Takeuchi O, Jeffers JR, Zambetti GP, Hsieh JJ, Cheng EH. Stepwise activation of BAX and BAK by tBID, BIM, and PUMA initiates mitochondrial apoptosis. Mol Cell. 2009; 36:487-499.

5. Tait SW, Green DR. Mitochondria and cell death: outer membrane permeabilization and beyond. Nat Rev Mol Cell Biol. 2010; 11:621-632.

6. Cheng EH, Wei MC, Weiler S, Flavell RA, Mak TW, Lindsten T, Korsmeyer SJ. BCL-2, BCL-X(L) sequester $\mathrm{BH} 3$ domain-only molecules preventing $\mathrm{BAX}-$ and BAK-mediated mitochondrial apoptosis. Mol Cell. 2001; 8:705-711.

7. Letai A, Bassik MC, Walensky LD, Sorcinelli MD, Weiler S, Korsmeyer SJ. Distinct BH3 domains either sensitize or activate mitochondrial apoptosis, serving as prototype cancer therapeutics. Cancer Cell. 2002; 2:183-192.

8. Willis SN, Chen L, Dewson G, Wei A, Naik E, Fletcher JI, Adams JM, Huang DCS. Proapoptotic Bak is sequestered by Mcl-1 and Bcl-x(L), but not Bcl-2, until displaced by BH3-only proteins. Gene Dev. 2005; 19:1294-1305.

9. Liu X, Dai S, Zhu Y, Marrack P, Kappler JW. The structure of a Bcl-xL/Bim fragment complex: implications for Bim function. Immunity. 2003; 19:341-352.

10. Czabotar PE, Lee EF, van Delft MF, Day CL, Smith BJ, Huang DCS, Fairlie WD, Hinds MG, Colman PM. Structural insights into the degradation of Mcl-1 induced by BH3 domains. P Natl Acad Sci USA. 2007; 104:6217-6222.

11. Oda E, Ohki R, Murasawa H, Nemoto J, Shibue T, Yamashita T, Tokino T, Taniguchi T, Tanaka N. Noxa, a BH3-only member of the Bcl-2 family and candidate mediator of p53-induced apoptosis. Science. 2000; 288:1053-1058.

12. She QB, Solit DB, Ye Q, O'Reilly KE, Lobo J, Rosen N. The BAD protein integrates survival signaling by EGFR/ MAPK and PI3K/Akt kinase pathways in PTEN-deficient tumor cells. Cancer Cell. 2005; 8:287-297.
13. Puthalakath H, O'Reilly LA, Gunn P, Lee L, Kelly PN, Huntington ND, Hughes PD, Michalak EM, McKimmBreschkin J, Motoyama N, Gotoh T, Akira S, Bouillet P, Strasser A. ER stress triggers apoptosis by activating BH3only protein Bim. Cell. 2007; 129:1337-1349.

14. Nakano K, Vousden KH. PUMA, a novel proapoptotic gene, is induced by p53. Mol Cell. 2001; 7:683-694.

15. Humphreys RC, Krajewska M, Krnacik S, Jaeger R, Weiher H, Krajewski S, Reed JC, Rosen JM. Apoptosis in the terminal endbud of the murine mammary gland: a mechanism of ductal morphogenesis. Development. 1996; 122:4013-4022.

16. Mailleux AA, Overholtzer M, Schmelzle T, Bouillet P, Strasser A, Brugge JS. BIM regulates apoptosis during mammary ductal morphogenesis, and its absence reveals alternative cell death mechanisms. Dev Cell. 2007; 12:221-234.

17. Metcalfe AD, Gilmore A, Klinowska T, Oliver J, Valentijn AJ, Brown R, Ross A, MacGregor G, Hickman JA, Streuli CH. Developmental regulation of Bcl-2 family protein expression in the involuting mammary gland. J Cell Sci. 1999; 112:1771-1783.

18. Rucker EB 3rd, Hale AN, Durtschi DC, Sakamoto K, Wagner KU. Forced involution of the functionally differentiated mammary gland by overexpression of the proapoptotic protein bax. Genesis. 2011; 49:24-35.

19. Walton KD, Wagner KU, Rucker EB 3rd, Shillingford JM, Miyoshi K, Hennighausen L. Conditional deletion of the bcl-x gene from mouse mammary epithelium results in accelerated apoptosis during involution but does not compromise cell function during lactation. Mech Dev. 2001; 109:281-293.

20. Tsujimoto Y, Finger LR, Yunis J, Nowell PC, Croce CM. Cloning of the chromosome breakpoint of neoplastic B cells with the $\mathrm{t}(14 ; 18)$ chromosome translocation. Science. 1984; 226:1097-1099.

21. Hanahan D, Weinberg RA. The hallmarks of cancer. Cell. 2000; 100:57-70.

22. Debnath J, Muthuswamy SK, Brugge JS. Morphogenesis and oncogenesis of MCF-10A mammary epithelial acini grown in three-dimensional basement membrane cultures. Methods. 2003; 30:256-268.

23. Debnath J, Mills KR, Collins NL, Reginato MJ, Muthuswamy SK, Brugge JS. The role of apoptosis in creating and maintaining luminal space within normal and oncogene-expressing mammary acini. Cell. 2002; 111:29-40.

24. Harris JR, M. Morrow, M.E. Lippman, C.K Osborne. Disease of the Breast. Philadelphia, PA. 2010.

25. Jager R, Herzer U, Schenkel J, Weiher H. Overexpression of Bcl-2 inhibits alveolar cell apoptosis during involution and accelerates c-myc-induced tumorigenesis of the mammary gland in transgenic mice. Oncogene. 1997; 15:1787-1795. 
26. Furth PA, Bar-Peled U, Li M, Lewis A, Laucirica R, Jager R, Weiher H, Russell RG. Loss of anti-mitotic effects of Bcl-2 with retention of anti-apoptotic activity during tumor progression in a mouse model. Oncogene. 1999; 18:6589-6596.

27. Shibata MA, Liu ML, Knudson MC, Shibata E, Yoshidome K, Bandey T, Korsmeyer SJ, Green JE. Haploid loss of bax leads to accelerated mammary tumor development in C3(1)/SV40-TAg transgenic mice: reduction in protective apoptotic response at the preneoplastic stage. EMBO J. 1999; 18:2692-2701.

28. Balko JM, Giltnane JM, Wang K, Schwarz LJ, Young CD, Cook RS, Owens P, Sanders ME, Kuba MG, Sanchez V, Kurupi R, Moore PD, Pinto JA, Doimi FD, Gomez H, Horiuchi $\mathrm{D}$, et al. Molecular profiling of the residual disease of triple-negative breast cancers after neoadjuvant chemotherapy identifies actionable therapeutic targets. Cancer Discov. 2014; 4:232-245.

29. Gee JM, Robertson JF, Ellis IO, Willsher P, McClelland RA, Hoyle HB, Kyme SR, Finlay P, Blamey RW, Nicholson RI. Immunocytochemical localization of BCL-2 protein in human breast cancers and its relationship to a series of prognostic markers and response to endocrine therapy. Int J Cancer. 1994; 59:619-628.

30. Ellis PA, Smith IE, Detre S, Burton SA, Salter J, A'Hern R, Walsh G, Johnston SR, Dowsett M. Reduced apoptosis and proliferation and increased Bcl-2 in residual breast cancer following preoperative chemotherapy. Breast Cancer Res Treat. 1998; 48:107-116.

31. Real PJ, Sierra A, De Juan A, Segovia JC, Lopez-Vega JM, Fernandez-Luna JL. Resistance to chemotherapy via Stat3dependent overexpression of Bcl-2 in metastatic breast cancer cells. Oncogene. 2002; 21:7611-7618.

32. Teixeira C, Reed JC, Pratt MA. Estrogen promotes chemotherapeutic drug resistance by a mechanism involving Bcl-2 proto-oncogene expression in human breast cancer cells. Cancer Research. 1995; 55:3902-3907.

33. Crawford A, Nahata R. Targeting Bcl-2 in Herceptin-Resistant Breast Cancer Cell Lines. Current Pharmacogenomics. 2011; 9:184-190.

34. Davies C, Godwin J, Gray R, Clarke M, Cutter D, Darby S, McGale P, Pan HC, Taylor C, Wang YC, Dowsett M, Ingle J, Peto R. Relevance of breast cancer hormone receptors and other factors to the efficacy of adjuvant tamoxifen: patient-level meta-analysis of randomised trials. Lancet. 2011; 378:771-784.

35. Musgrove EA, Sutherland RL. Biological determinants of endocrine resistance in breast cancer. Nat Rev Cancer. 2009; 9:631-643.

36. Zhou H, Zhang Y, Fu Y, Chan L, Lee AS. Novel mechanism of anti-apoptotic function of 78-kDa glucose-regulated protein (GRP78): endocrine resistance factor in breast cancer, through release of B-cell lymphoma 2 (BCL-2) from BCL-2-interacting killer (BIK). Journal of Biological Chemistry. 2011; 286:25687-25696.
37. Oltersdorf T, Elmore SW, Shoemaker AR, Armstrong RC, Augeri DJ, Belli BA, Bruncko M, Deckwerth TL, Dinges J, Hajduk PJ, Joseph MK, Kitada S, Korsmeyer SJ, Kunzer AR, Letai A, Li C, et al. An inhibitor of Bcl-2 family proteins induces regression of solid tumours. Nature. 2005; 435:677-681.

38. Tse C, Shoemaker AR, Adickes J, Anderson MG, Chen J, Jin S, Johnson EF, Marsh KC, Mitten MJ, Nimmer P, Roberts L, Tahir SK, Xiao Y, Yang X, Zhang H, Fesik S, et al. ABT-263: a potent and orally bioavailable Bcl-2 family inhibitor. Cancer Research. 2008; 68:3421-3428.

39. Roberts AW, Seymour JF, Brown JR, Wierda WG, Kipps TJ, Khaw SL, Carney DA, He SZ, Huang DC, Xiong H, Cui Y, Busman TA, McKeegan EM, Krivoshik AP, Enschede SH, Humerickhouse R. Substantial susceptibility of chronic lymphocytic leukemia to BCL2 inhibition: results of a phase I study of navitoclax in patients with relapsed or refractory disease. J Clin Oncol. 2012; 30:488-496.

40. Wilson WH, O'Connor OA, Czuczman MS, LaCasce AS, Gerecitano JF, Leonard JP, Tulpule A, Dunleavy K, Xiong H, Chiu YL, Cui Y, Busman T, Elmore SW, Rosenberg SH, Krivoshik AP, Enschede SH, et al. Navitoclax, a targeted high-affinity inhibitor of BCL-2, in lymphoid malignancies: a phase 1 dose-escalation study of safety, pharmacokinetics, pharmacodynamics, and antitumour activity. Lancet Oncol. 2010; 11:1149-1159.

41. Davids MS, RA, Anderson MA, Pagel JM, Kahl BS, Gerecitano JF, et al. The BCL-2-specific-mimetic ABT-199 (GDC-0199) is active and well-tolerated in patients with relapsed non-Hodgkin lymphoma: interim results of a phase I study [abstract]. Proceedings of the 54th ASH Annual Meeting and Exposition; 2012; Atlanta, GA.

42. Souers AJ, Leverson JD, Boghaert ER, Ackler SL, Catron ND, Chen J, Dayton BD, Ding H, Enschede SH, Fairbrother WJ, Huang DC, Hymowitz SG, Jin S, Khaw SL, Kovar PJ, Lam LT, et al. ABT-9, a potent and selective BCL-2 inhibitor, achieves antitumor activity while sparing platelets. Nat Med. 2013; 19:202-208.

43. A Phase 1 Study Evaluating the Safety and Pharmacokinetics of ABT-199 in Subjects With Relapsed or Refractory Chronic Lymphocytic Leukemia and Non-Hodgkin Lymphoma.

44. Perillo B, Sasso A, Abbondanza C, Palumbo G. 17betaestradiol inhibits apoptosis in MCF-7 cells, inducing bcl-2 expression via two estrogen-responsive elements present in the coding sequence. Mol Cell Biol. 2000; 20:2890-2901.

45. Vaillant F, Merino D, Lee L, Breslin K, Pal B, Ritchie ME, Smyth GK, Christie M, Phillipson LJ, Burns CJ, Mann GB, Visvader JE, Lindeman GJ. Targeting BCL-2 with the BH3 mimetic ABT-199 in estrogen receptor-positive breast cancer. Cancer Cell. 2013; 24:120-129.

46. Oakes SR, Vaillant F, Lim E, Lee L, Breslin K, Feleppa F, Deb S, Ritchie ME, Takano E, Ward T, Fox SB, Generali D, Smyth GK, Strasser A, Huang DC, Visvader JE, et al. 
Sensitization of BCL-2-expressing breast tumors to chemotherapy by the BH3 mimetic ABT-737. Proc Natl Acad Sci U S A. 2012; 109:2766-2771.

47. Li JY, Li YY, Jin W, Yang Q, Shao ZM, Tian XS. ABT737 reverses the acquired radioresistance of breast cancer cells by targeting Bcl-2 and Bcl-xL. J Exp Clin Cancer Res. 2012; 31:102.

48. Campone M, Noel B, Couriaud C, Grau M, Guillemin Y, Gautier F, Gouraud W, Charbonnel C, Campion L, Jezequel P, Braun F, Barre B, Coqueret O, Barille-Nion S, Juin P. c-Myc dependent expression of pro-apoptotic Bim renders HER2-overexpressing breast cancer cells dependent on anti-apoptotic Mcl-1. Mol Cancer. 2011; 10.

49. Gandhi L, Camidge DR, Ribeiro de Oliveira M, Bonomi P, Gandara D, Khaira D, Hann CL, McKeegan EM, Litvinovich E, Hemken PM, Dive C, Enschede SH, Nolan C, Chiu YL, Busman T, Xiong H, et al. Phase I study of Navitoclax (ABT-263), a novel Bcl-2 family inhibitor, in patients with small-cell lung cancer and other solid tumors. J Clin Oncol. 2011; 29:909-916.

50. 2014; Safety Study of ABT-263 in Combination With Paclitaxel in Subjects With Solid Tumors.

51. 2011; Safety Study of ABT-263 in Combination With Gemzar (Gemcitabine) in Subjects With Solid Tumors.

52. 2014; Navitoclax and Sorafenib Tosylate in Treating Patients With Relapsed or Refractory Solid Tumors.

53. Joensuu H, Pylkkanen L, Toikkanen S. Bcl-2 protein expression and long-term survival in breast cancer. Am J Pathol. 1994; 145:1191-1198.

54. cbioportal.org. 2014; In: Atlas, TCG, ed.

55. Thomas LW, Lam C, Edwards SW. Mcl-1, the molecular regulation of protein function. Febs Lett. 2010; 584:2981-2989.

56. Juin P, Geneste O, Gautier F, Depil S, Campone M. Decoding and unlocking the BCL-2 dependency of cancer cells. Nat Rev Cancer. 2013; 13:455-465.

57. Ding Q, Huo L, Yang JY, Xia W, Wei Y, Liao Y, Chang CJ, Yang Y, Lai CC, Lee DF, Yen CJ, Chen YJ, Hsu JM, Kuo HP, Lin CY, Tsai FJ, et al. Down-regulation of myeloid cell leukemia-1 through inhibiting Erk/Pin 1 pathway by sorafenib facilitates chemosensitization in breast cancer. Cancer Research. 2008; 68:6109-6117.

58. Mills JR, Hippo Y, Robert F, Chen SM, Malina A, Lin CJ, Trojahn U, Wendel HG, Charest A, Bronson RT, Kogan SC, Nadon R, Housman DE, Lowe SW, Pelletier J. mTORC1 promotes survival through translational control of Mcl-1. Proc Natl Acad Sci U S A. 2008; 105:10853-10858.

59. Kuo ML, Chuang SE, Lin MT, Yang SY. The involvement of PI3-K/Akt-dependent up-regulation of Mcl-1 in the prevention of apoptosis of Hep3B cells by interlenkin-6. Oncogene. 2001; 20:677-685.
60. Jebahi A, Villedieu M, Petigny-Lechartier C, Brotin E, Louis MH, Abeilard E, Giffard F, Guercio M, Briand M, Gauduchon P, Lheureux S, Poulain L. PI3K/mTOR dual inhibitor NVP-BEZ235 decreases Mcl-1 expression and sensitizes ovarian carcinoma cells to Bcl-xL-targeting strategies, provided that Bim expression is induced. Cancer Lett. 2014; 348:38-49.

61. Faber AC, Coffee EM, Costa C, Dastur A, Ebi H, Hata AN, Yeo AT, Edelman EJ, Song Y, Tam AT, Boisvert JL, Milano RJ, Roper J, Kodack DP, Jain RK, Corcoran RB, et al. mTOR Inhibition Specifically Sensitizes Colorectal Cancers with KRAS or BRAF Mutations to BCL-2/ BCL-XL Inhibition by Suppressing MCL-1. Cancer Discovery. 2014; 4:42-52.

62. Ding Q, He X, Xia W, Hsu JM, Chen CT, Li LY, Lee DF, Yang JY, Xie X, Liu JC, Hung MC. Myeloid cell leukemia-1 inversely correlates with glycogen synthase kinase3 beta activity and associates with poor prognosis in human breast cancer. Cancer Research. 2007; 67:4564-4571.

63. Mitchell C, Yacoub A, Hamed H, Martin AP, Bareford MD, Eulitt P, Yang C, Nephew KP, Dent P. Inhibition of MCL-1 in breast cancer cells promotes cell death in vitro and in vivo. Cancer Biol Ther. 2010; 10:907-921.

64. Yecies D, Carlson NE, Deng J, Letai A. Acquired resistance to ABT-737 in lymphoma cells that up-regulate MCL-1 and BFL-1. Blood. 2010; 115:3304-3313.

65. Mazumder S, Choudhary GS, Al-harbi S, Almasan A. Mcl-1 Phosphorylation Defines ABT-737 Resistance That Can Be Overcome by Increased NOXA Expression in Leukemic B cells. Cancer Research. 2012; 72:3069-3079.

66. Morales AA, Kurtoglu M, Matulis SM, Liu JX, Siefker D, Gutman DM, Kaufman JL, Lee KP, Lonial S, Boise LH. Distribution of Bim determines Mcl-1 dependence or codependence with $\mathrm{Bcl}-\mathrm{x}(\mathrm{L}) / \mathrm{Bcl}-2$ in Mcl-1-expressing myeloma cells. Blood. 2011; 118:1329-1339.

67. Konopleva M, Contractor R, Tsao T, Samudio I, Ruvolo PP, Kitada S, Deng X, Zhai D, Shi YX, Sneed T, Verhaegen M, Soengas M, Ruvolo VR, McQueen T, Schober WD, Watt JC, et al. Mechanisms of apoptosis sensitivity and resistance to the $\mathrm{BH} 3$ mimetic $\mathrm{ABT}-737$ in acute myeloid leukemia. Cancer Cell. 2006; 10:375-388.

68. Tromp JM, Geest CR, Breij EC, Elias JA, van Laar J, Luijks DM, Kater AP, Beaumont T, van Oers MH, Eldering E. Tipping the Noxa/Mcl-1 balance overcomes ABT-737 resistance in chronic lymphocytic leukemia. Clin Cancer Res. 2012; 18:487-498.

69. Tahir SK, Wass J, Joseph MK, Devanarayan V, Hessler P, Zhang H, Elmore SW, Kroeger PE, Tse C, Rosenberg SH, Anderson MG. Identification of expression signatures predictive of sensitivity to the Bcl-2 family member inhibitor ABT-263 in small cell lung carcinoma and leukemia/lymphoma cell lines. Mol Cancer Ther. 2010; 9:545-557. 
70. Belmar J, Fesik SW. Small molecule Mcl-1 inhibitors for the treatment of cancer. Pharmacol Ther. 2014; .

71. Doi K, Li R, Sung SS, Wu H, Liu Y, Manieri W, Krishnegowda G, Awwad A, Dewey A, Liu X, Amin S, Cheng C, Qin Y, Schonbrunn E, Daughdrill G, Loughran TP Jr., et al. Discovery of marinopyrrole A (maritoclax) as a selective Mcl-1 antagonist that overcomes ABT-737 resistance by binding to and targeting Mcl-1 for proteasomal degradation. Journal of Biological Chemistry. 2012; 287:10224-10235

72. Abulwerdi F, Liao C, Liu M, Azmi AS, Aboukameel A, Mady AS, Gulappa T, Cierpicki T, Owens S, Zhang T, Sun D, Stuckey JA, Mohammad RM, NikolovskaColeska Z. A novel small-molecule inhibitor of mcl-1 blocks pancreatic cancer growth in vitro and in vivo. Mol Cancer Ther. 2014; 13:565-575. 